UDC 577.112.5+577.164.15+616.43

\title{
EFFECT OF NICOTINAMIDE ON AMINO ACIDS CONTENT IN BONE COLLAGEN DEPENDING ON BIOLOGICAL AVAILABILITY OF VITAMINS IN DIABETIC RATS
}

\author{
M. M. GUZYK ${ }^{1}$, IU. T. SERGIICHUK ${ }^{1,2}$, K. O. DYAKUN $N^{1,2}$, \\ L. V. YANITSKA ${ }^{3}$, T. M. KUCHMEROVSKA ${ }^{1}$ \\ ${ }^{1}$ Palladin Institute of Biochemistry, National Academy of Sciences of Ukraine, Kyiv; \\ e-mail: kuch@biochem.kiev.ua; \\ ${ }^{2}$ Taras Shevchenko Kyiv National University, Ukraine; \\ ${ }^{3}$ O. O. Bogomolets National Medical University, Kyiv;
}

\begin{abstract}
Connective tissue is highly susceptible to imbalances induced by diabetes. Diabetes-related osteopenia, decreased bone strength etc. may be associated with altered metabolism of various collagens. Although it is assumed that alterations in collagen amino acids (AA) may strongly affect protein properties and physiological functions, however, very limited evidences are present at the moment regarding AA composition of bone type I collagen and its relevance to abnormal availability of vitamins which are necessary for collagen synthesis in diabetes. We have tested whether nicotinamide (NAm) can influence type I collagen formation and AA composition as well as vitamins availability in diabetes. After 4 weeks of STZ-induced diabetes (60 mg/ $\mathrm{kg}$ ) male Wistar rats were injected for 2 weeks with/without NAm (200 mg/kg b. w.). Acid extraction of type I collagen from the bones was performed with following stepwise salting out. The content of type I collagen after its acid extraction from the bones was estimated by the amounts of hydroxyproline. Amino acids were assayed by cation exchange chromatography. Diabetes-associated changes in AA composition of type I collagen mainly affect those amino acids which are known to be involved in helix formation and cross-linking of the molecules. Diabetes was found to significantly reduce bone collagen contents of o-Pro, Gly, Ala, o-Lys and Pro, whereas Lys, His, Arg, Glu, Thr, Leu, Phe contents were elevated $(P<0.05)$. NAm treatment was able to partially normalise AA contents. In diabetes, blood serum and hepatic vitamin $C$ and $B_{3}$ contents were shown to be significantly lowered, whereas $\alpha$-tocopherol was slightly increased compared with control $(P<0.05)$. Restoration of circulatory and liver vitamin $C$ and $B_{3}$ was observed. The data demonstrate the close relationship between the diabetes-associated decrease in type I collagen deposition, altered amino acids metabolism and impaired availability of vitamins, which are necessary for collagen synthesis. Thus, NAm might be a useful agent for treatment of bone failures related to diabetes.
\end{abstract}

Key words: nicotinamide, STZ-diabetes in rats, bone collagen amino acids, vitamin $C$, vitamin $B_{3}$, $\alpha$-tocopherol.

$\mathrm{T}$ ype 1 diabetes results from active immunemediated destruction of insulin-producing $\beta$-cells in the pancreas by T-cells and macrophages infiltrating the islets [1]. It is likely that many pathways may lead to autoimmune destruction of the islet $\beta$-cells and actual mechanism in each individual depends on genetics and environment [2].

The results of numerous investigations clearly demonstrate that modern diabetes pharmacological treatment is unable to prevent completely diabetes complications among which cardiovascular disease and nephropathy have the highest levels of incidence and the poorest prognosis [3, 4]. It is known that dur- ing this disease proteins are targets for numerous injuries and could have pathologically altered turnover rates.

Connective tissue disturbances and especially qualitative changes of collagen synthesis always accompany these pathological processes [5]. Diabetes induces structural and functional changes of the extracellular matrix proteins in many tissues [6]. It could not be excluded that alterations in levels of bone collagen amino acids may contribute to diabetes.

Processing and secretion of collagen was previously shown to be controlled by insulin at a post- 
transcriptional site [7]. Other authors demonstrated that the $\alpha 2$ (I) collagen gene contains two functional promoters, and its expression in cells is regulated at both transcriptional and post-transcriptional levels [8]. On the other hand there were no evidences of qualitative changes in connective tissue collagens caused by lack of insulin. Diabetes-related connective tissue changes, as osteopenia and decreased bone strength may be associated with altered metabolism of type I collagen [9]. Moreover, the bone mass and postmenopausal bone loss with gradual destruction of trabecular bone architecture are the major skeletal determinants of fracture risk and development of osteoporosis [10]. Bone fractures, especially of long bones or large joints are a major diabetic disorders and often not followed by successful recovery.

Type I collagen, as the bone major protein component, makes up more than $90 \%$ of the dry bone weight, and is subject to continuous synthesis and degradation in response to mechanical stress and signaling events. It is assumed that alterations in type I collagen amino acids as a result of gene polymorphism may strongly affect protein properties and physiological functions; however, very limited evidences are present at the moment regarding amino acid composition of type I collagens from rat bones and its relevance to abnormal availability of vitamins which are necessary for collagen synthesis under diabetes.

Available data indicate that the both vitamins $\mathrm{C}$ and $\mathrm{E}$ are useful compounds for collagen turnover. It is well known that L-ascorbic acid plays a key role as a cofactor in the post-translational modification of collagen molecules and in promoting collagen, carnitine and neurotransmitters biosynthesis [11]. Vitamin E can suppress bone resorption, while stimulating bone formation and skeletal health in vivo with advancing age [12]. Moreover vitamin E ( $\alpha$-tocopherol) has positive characteristics to bone regeneration [13]. However, contradictory data regarding the role of vitamin $\mathrm{E}$ in collagen synthesis exist, indicating both inhibitory and stimulatory effects.

An increasing amount of evidences has demonstrated that vitamin $\mathrm{B}_{3}$ (nicotinamide, nicotinic acid) has important physiological and pharmacological action. It is still the most efficacious drug in terms of its ability to influence many metabolic processes. This water-soluble vitamin was found to improve beta cell survival in various animal models, including oxygen radical, streptozotocin and nitric oxide toxicity, induces differentiation of embryonic stem cells into insulin-secreting cells, etc. [14, 15]. We hypothesized that nicotinamide may influence the biosynthesis of collagen in diabetes via pyridine dinucleotides, firstly, by normalization of amino acids metabolism and, secondly, due to NADPH-dependent regeneration of vitamin $\mathrm{C}$ with consequent restoration of tocopherols. Nevertheless, few studies have also reported that vitamin $\mathrm{B}_{3}$ inhibits the expression of type I and type III procollagen genes at the level of gene transcription in the bleomycin hamster model of lung fibrosis.

This study was designed to estimate putative changes in the rat bone collagen amino acids composition in streptozotocin-induced diabetes and to define the character of functional interplay between vitamins availability and changes in formation of type I collagen in bones. We also tested whether nicotinamide, as a drug with the wide range of metabolic effects, can influence collagen impairments associated with diabetes in a high therapeutic dose.

\section{Materials and Methods}

Unless otherwise stated, all chemicals were of reagent-grade quality. Streptozotocin (STZ), NAm, pepsin $(3200 \mathrm{U} / \mathrm{mg})$ and pepstatin were purchased from Sigma Chemical Co., USA. Polyclonal antibody against cytochrome P450 2E1 (CYP 2E1) was obtained from Amersham (Piscataway, NJ). Reagents for electrophoresis and Western blotting were purchased from Bio-Rad (Richmond, CA).

The experiments were performed on male Wistar rats with the body weight of approximately 250-270 g, fed with a standard rat laboratory diet and with free access to food and water. Following 1 week of acclimation, animals were randomly assigned to treatment groups. Diabetes was induced by a single intraperitoneal injection of freshly prepared solution of streptozotocin $(60 \mathrm{mg} / \mathrm{kg}$ of body weight) dissolved in citrate buffer ( $\mathrm{pH} 4.5)$, while the control group was injected with the buffer only. Body weights of all the animals were recorded weakly, prior to the treatments and sacrifice. Animals were maintained on $12 \mathrm{~h}$ light/dark cycle and randomly divided into the following groups: 1) control group; 2) diabetic group with 6-week duration of diabetes; 3) diabetic groups with 4-week duration of diabetes treated with nicotinamide at a dose of $200 \mathrm{mg} / \mathrm{kg} /$ day, intraperitoneally for 2 weeks. The rats with blood glucose level over $18.5 \mathrm{mmol} / 1$ were taken 
into experiments. All procedures were carried out in accordance with the national and international guidelines and laws concerning animal welfare and are ethically acceptable. After 6 weeks the rats of experimental and control groups were sacrificed via cervical dislocation under mild diethyl ether narcosis.

The blood samples of each animal were taken by puncturing retro-orbital plexus and allowed it to clot for 1 hour at a room temperature. Then serum was separated by centrifugation at $400 \mathrm{~g}$ for $15 \mathrm{~min}$ at $25{ }^{\circ} \mathrm{C}$ and analyzed for biochemical parameters. Plasma glucose levels were determined by Glukometer Precision Xtra Plus (MediSense UK Ltd., Oxon, UK). Vitamin $C$, $\alpha$-tocopherol and vitamin $\mathrm{B}_{3}$ levels were respectively assessed according to methods [16-18]. The serum alkaline phosphatase (ALP), [EC 3.1.3.1] activity was determined using 4-nitrophenyl phosphate as substrate [19]. The expression of CYP 2E1 was assessed by electrophoresis and immunoblotting.

Several methods of bone type I collagen isolation from both Tibia and Fibula and its purification were used - the extraction with neutral salt, acid and enzymatic solutions [20-22]. After demineralizations three times (all for 24 hours at $4{ }^{\circ} \mathrm{C}$ ) with $0.5 \mathrm{M}$ disodium-EDTA (adjusted to $\mathrm{pH} 7.4$ with ammonia) bone pieces were extracted in $0.5 \mathrm{M}$ acetic acid and centrifuged at $6000 \mathrm{~g}$ for $20 \mathrm{~min}$. The precipitates were dissolved in $0.5 \mathrm{M}$ acetic acid in the presence of $5 \mathrm{mM}$ EDTA and pepsin $(50 \mathrm{mg}$ per $1 \mathrm{~g}$ of tissue, $\mathrm{pH} 2.5$ for 96 hour at $4{ }^{\circ} \mathrm{C}$ ). The enzymatic reaction was stopped by adding pepstatin to $\mathrm{pH} 7.5$. The precipitates were discarded by centrifugation at $3500 \mathrm{~g}$ for $40 \mathrm{~min}$ and supernatants were collected and salted out with $4 \mathrm{M} \mathrm{NaCl}$. The obtained precipitates that contained pure collagen were dissolved in $1 \mathrm{M}$ acetic acid. Then the solutions were dialyzed against $0.02 \mathrm{M} \mathrm{Na}_{2} \mathrm{HPO}_{4}$ for 24 hours at $4{ }^{\circ} \mathrm{C}$ and centrifuged at $6500 \mathrm{~g}$ for $60 \mathrm{~min}$. Collagen preparations purity was controlled electrophoretically.

Collagen fractions were hydrolyzed by $6 \mathrm{~N} \mathrm{HCl}$ during 24 hours, at $105{ }^{\circ} \mathrm{C}$ and their amino acids composition was analyzed by cation exchange chromatography on the amino acid analyzer AAA- 881 (Czech Republic).

All data are expressed as the Mean \pm SEM. Differences in means between groups were tested using the Mann-Whitney $U$ test and considered to be statistically significant at $P<0.05$.

\section{Results and Discussions}

Initial body weights of control and diabetic rats were similar (Table 1).

After six weeks of diabetes induction the body weight was lowered by over $25 \%$ than those of the age-matched diabetic rats at the beginning of experiments. In our studies NAm treatment statistically did not affect weight gain in diabetic rats. As expected, hyperglycemia was maintained throughout the study period and by the end of the sixth week blood glucose was 3.68 times higher in diabetic rats compared with its initial concentration. Treatment with NAm had a slight lowering effect on blood glucose concentrations in diabetic rats (Table 1).

Because growing evidence indicates that hyperglycemia can produce abnormalities in collagen cross-linking, the process which is thought to play an important role in the biological and biomechanical features of bones, it was important to determine whether type I collagen from bones of diabetic rats had alterations in AA residues involved in posttranslational modification of collagen.

The amino acids composition of the type I collagen revealed significant differences between control and diabetic bones in respect of a possible decrease in lysine and proline hydroxylations. Type I collagen contents from both Tibia and Fibula bones

Ta ble 1. Initial and final body weights and blood glucose concentrations in control and diabetic rats with and without NAm (200 mg/kg b.w.) treatment $(n=6)$

\begin{tabular}{l|c|c|c|c}
\hline Groups of animals & $\begin{array}{c}\text { Initial body } \\
\text { weight, } g\end{array}$ & $\begin{array}{c}\text { Final body } \\
\text { weight, g }\end{array}$ & $\begin{array}{c}\text { Initial plasma } \\
\text { glucose, mmol/1 }\end{array}$ & $\begin{array}{c}\text { Final plasma } \\
\text { glucose, mmol/1 }\end{array}$ \\
\hline Control & $256.3 \pm 12.4$ & $337.7 \pm 15.3$ & $5.3 \pm 0.4$ & $5.8 \pm 0.6$ \\
Diabetes & $257.3 \pm 12.7$ & $194.2 \pm 10.7^{*}$ & $6.3 \pm 0.7$ & $23.2 \pm 1.9^{*}$ \\
Diabetes+ NAm & $200.3 \pm 11.2$ & $219.1 \pm 11.5$ & $18.5 \pm 1.6^{* *}$ & $16.9 \pm 1.3^{* *}$ \\
\hline
\end{tabular}

Each value represents Mean \pm SEM. * Significantly different compared with those in controls $(P<0.05)$. ** Significantly different compared with those in untreated diabetes $(P<0.05)$. 
were lower in diabetes and in NAm-treated vs. control as it is evident from 3.67- and 1.96-fold decrease in Hyp contents, respectively (Fig. 1). Diabetes-associated changes in amino acids composition of type I collagen mainly affected those AA which are known to be involved in helix formation, cross-linking and charging of the molecules. Alterations in the rat bone type I collagen amino acids contents induced by type 1 diabetes were profound in bones as compared to control (Table 2). Statistically significant changes were registered in bones collagen for 17 amino acids.

Bone type I collagen of diabetic rats contains reliably 1.8-fold lower contents of hydroxylysine, 3.7-fold lower of hydroxyproline, 1.5-fold of proline, 1.9-fold of glycine and 1.3-fold of alanine, in other words lower contents of all amino acid residues which caused principal effects on collagen helix structure, rigidity and cross-linking [23]. A 1.8-fold decrease in hydroxylysine residues along with 1.5-

Table 2. Rat bones type I collagen amino acids content in control, diabetes and nicotinamidetreated diabetes $(n=6)$

\begin{tabular}{l|c|c|c}
\hline Amino acid & Control & Diabetes & $\begin{array}{c}\text { Diabetes + } \\
\text { NAm }\end{array}$ \\
\hline Hydroxylysine & 7 & $4^{*}$ & 5 \\
Lysine & 39 & $58^{*}$ & $49^{\#}$ \\
Histidine & 5 & $11^{*}$ & $8^{\#}$ \\
Arginine & 48 & 70 & 56 \\
Aspartic acid & 39 & $116^{*}$ & $96^{\#}$ \\
Threonine & 24 & $37^{*}$ & $30^{\#}$ \\
Serine & 38 & $52^{*}$ & $43^{\#}$ \\
Glutamic acid & 98 & $135^{*}$ & 134 \\
Proline & 102 & $70^{*}$ & $92^{\#}$ \\
Glycine & 304 & $164^{*}$ & $181^{\#}$ \\
Alanine & 109 & $81^{*}$ & $90^{\#}$ \\
Valine & 23 & $28^{*}$ & $22^{\#}$ \\
Methionine & 6 & $14^{*}$ & 13 \\
Isoleucine & 14 & $23^{*}$ & 22 \\
Leucine & 28 & $63^{*}$ & 64 \\
Tyrosine & 5 & $10^{*}$ & $8^{\#}$ \\
Phenylalanine & 12 & $37^{*}$ & 34 \\
\hline
\end{tabular}

Each value represents Mean of residues per 1000 residues. * Significantly different compared with those in controls $(P<0.05)$. \# Significantly different compared with those in untreated diabetes $(P<0.05)$.

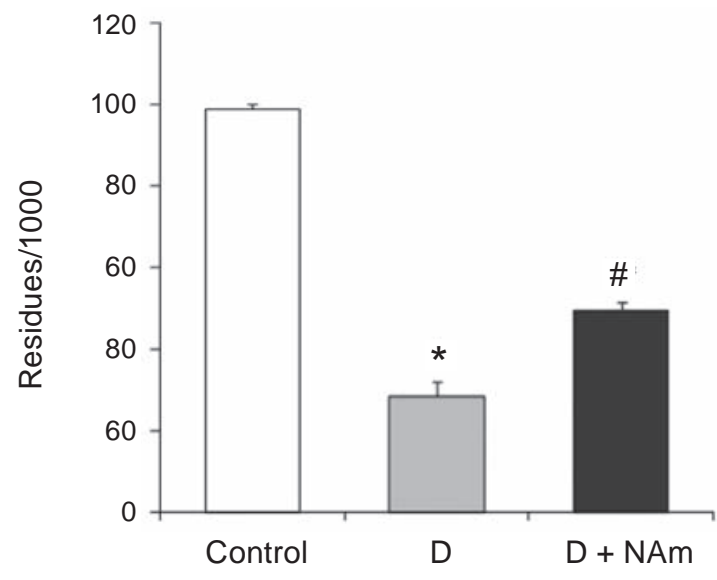

Fig. 1. Hydroxyproline content of type I collagen from rat bones. Each value represents Mean of residues per 1000 residues $(n=6)$. Here and in Fig. 2-6: D - diabetes, NAm - nicotinamide; *significantly different compared with those in controls $(P<0.05) ;{ }^{*}$ significantly different compared with those in untreated diabetes $(P<0.05)$

fold increase of lysine and 2.2-fold of histidine also participates in collagen cross-linking.

In our experiments contents of lysine, histidine, arginine, aspartic acid, threonine, serine, glutamic acid, methionine, isoleucine, leucine, tyrosine and phenylalanine in bones were increased. The Fischer ratio, the molar ratio of branched chain amino acids to aromatic amino acids ( $\mathrm{Leu}+\mathrm{Ile}+\mathrm{Val} / \mathrm{Tyr}+\mathrm{Phe}$ ), was shown to be decreased 2.43 vs. 3.82 times in control (Fig. 2). The present study provides evidence that NAm supplementation results in partial restoration of AA content in rat bones collagens. This nor-

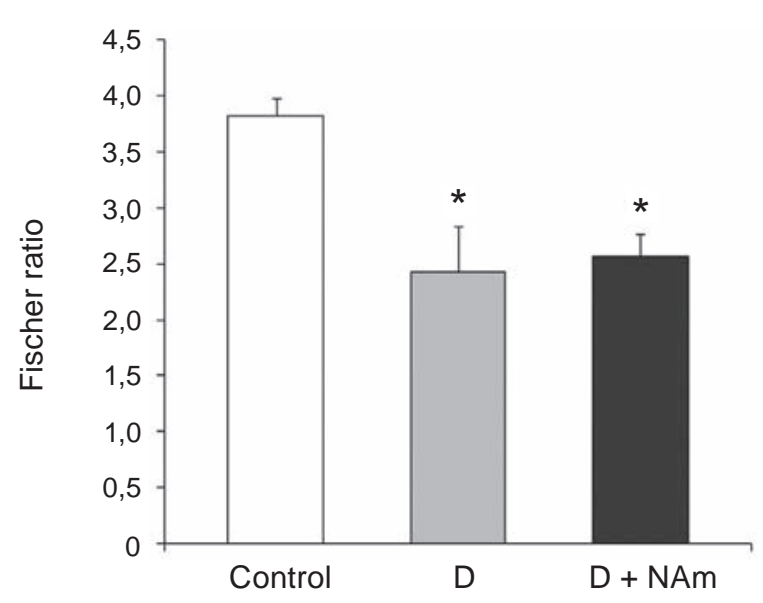

Fig. 2. Fischer ratio $(\mathrm{Leu}+\mathrm{Ile}+\mathrm{Val} / \mathrm{Ty}+\mathrm{Phe})$ in rat bones $(n=6)$ 


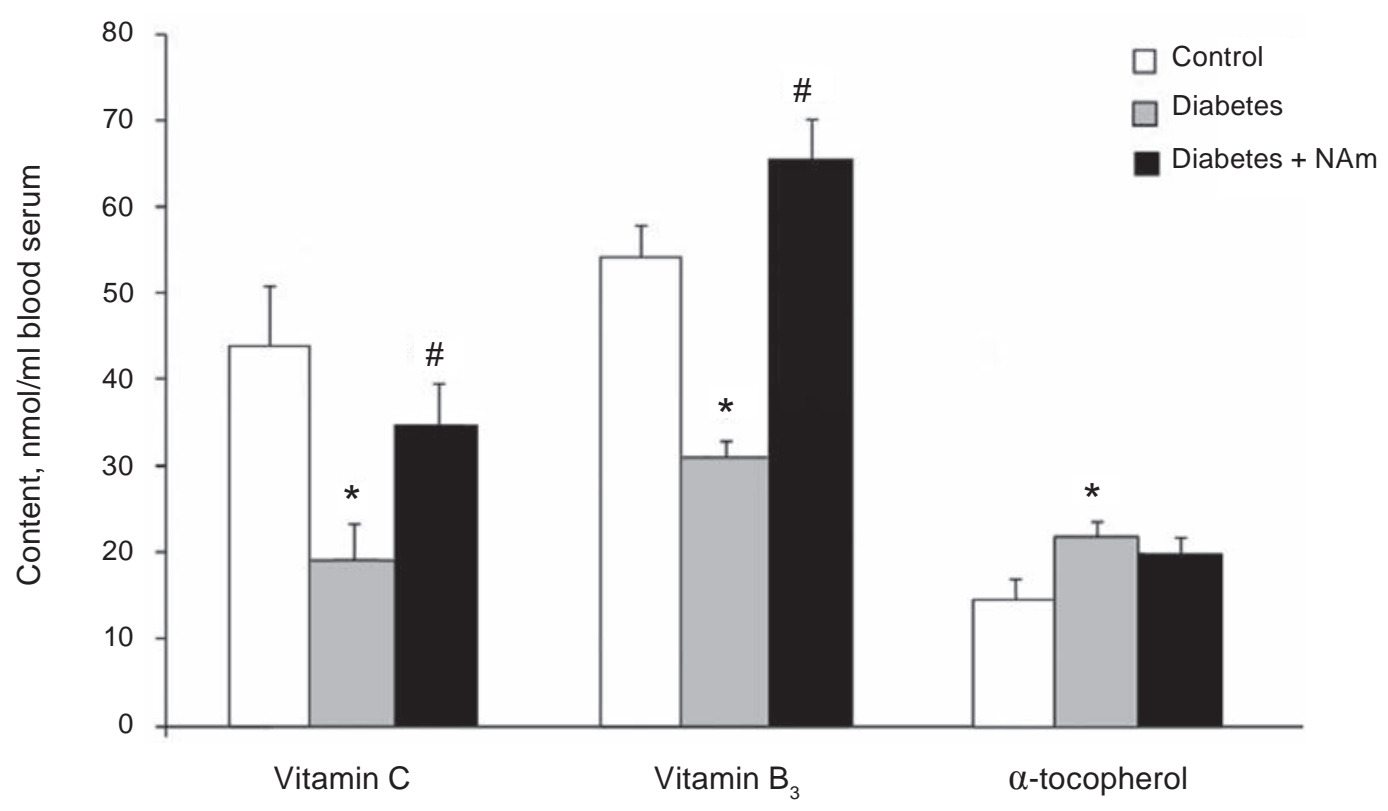

Fig. 3. Vitamin $C, B_{3}$ and $\alpha$-tocopherol contents in rat blood serum, nmol/ml blood serum. Data are expressed as $M \pm \operatorname{SEM}(n=6)$

malizing effect concerned for the most quantity of amino acid residues which could take influence on the collagen molecule surface charge: aspartic acid, threonine and serine. Despite partial normalizing of proline residues contents, its level remained lower than in control.

Vitamins $\mathrm{C}$ and $\mathrm{B}_{3}$ content was significantly reduced both in blood serum (Fig. 3) and liver (Fig. 4) in diabetes vs control, while the level of $\alpha$-tocopherol, the most abundant and active scaven-

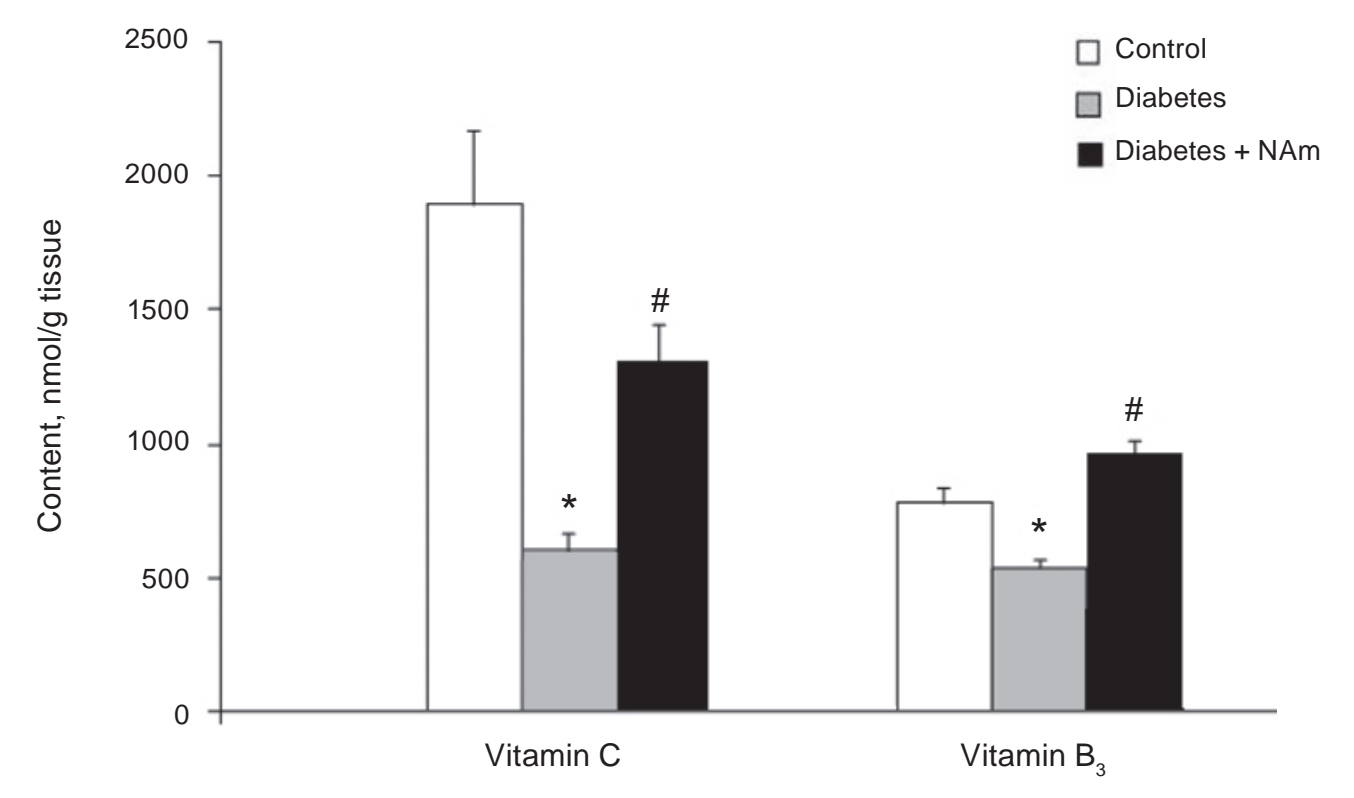

Fig. 4. Vitamin $C$ and $B_{3}$ contents in rat livers, $n$ mol/g tissue. Data are expressed as $M \pm \operatorname{SEM}(n=6)$

ger of peroxyl radicals, was augmented (Fig. 3 and 4). Impaired availability of the vitamins may be ascribed to their increased consumption by elevated oxidative stress identified in various tissues from diabetic rats and may also be due to reduced NADPHdependent regeneration of vitamin $\mathrm{C}$, since its level was reversed towards normalisation after NAm treatment (Fig. 3 and 4). Restoration of circulatory and liver vitamin $\mathrm{B}_{3}$ contents and slight decrease in vitamin $E$ levels were seen as a result of treatment. 
Diabetes induced a significant elevation in the level of serum alkaline phosphatase as compared to the control value (Fig. 5). It is known that serum total alkaline phosphatase is an ubiquitous, membranebound tetrameric enzyme attached to glycosylphosphatidylinositol moieties located on the outer cell surface [24]. The precise physiological role of alkaline phosphatase is unknown, although evidence suggests it is involved in bone mineralization and resorption [25]. Its alterations in serum can be due to changes of bone isoenzymes [26]. Chronic supplementation of NAm could partially improve changes of collagen structure by normalizing of vitamin C content as shown in Fig. 2 and 3 and reducing ALP serum activity.

Furthermore, CYP 2E1-dependent oxidative stress following the induction of CYP 2E1 by STZ is believed to be one of the main causes of hepatotoxicity. It was found more than 2.5-fold increase of CYP 2E1 expression in diabetic rats as compared to controls, while the NAm slightly reduced it (Fig. 6). It is possible that NAm may partially reduce the level of oxidative stress-related cellular toxicity produced by CYP 2E1 induction in type 1 diabetes. It is not excluded, that exacerbation in mean CYP 2E1 expression in the livers of diabetic rats and animals treated with NAm may be associated directly or indirectly with elevated plasma ketone levels.

Studies of putative changes in composition of bone collagens amino acids in diabetic rats and qualitative changes of collagen synthesis provide new information which can be used to determine the role of abnormal collagen metabolism in the development of diabetic complications.

In our experiments the decreased levels of hydroxyproline, proline and glycine inevitably affected

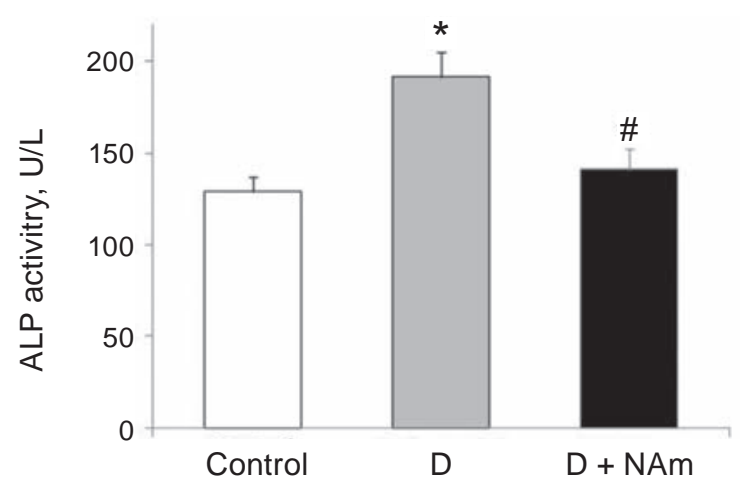

Fig. 5. Serum alkaline phosphatase (ALP) activity in control and diabetic rats. Data are expressed as $M \pm \operatorname{SEM}(n=6)$

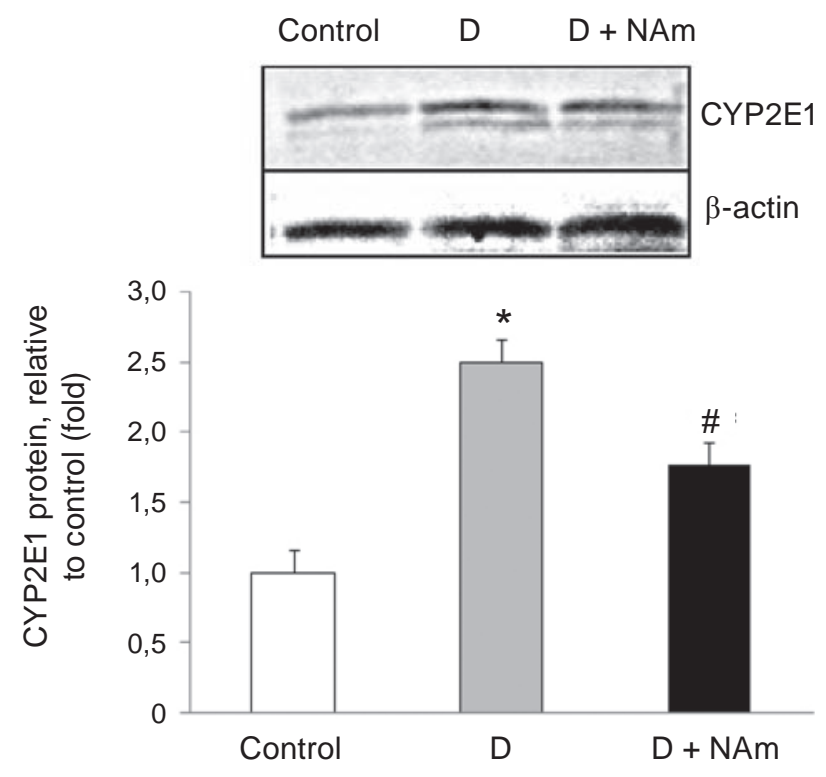

Fig. 6. Expression of CYP 2E1 protein in rat liver tissues. Bar plot shows the levels of each protein, expressed as $M \pm \operatorname{SEM}(n=6)$

collagen helix properties, since in normal conditions its structure is presumed to consist of triplets Gly-XPro or Gly-X-Hyp. Our findings are in close agreement with the data of other authors which demonstrated disturbances of collagen ultrastructure with streptozotocin-induced diabetes [27, 28]. Changes in the ratio of hydroxylysine: lysine: histidine residues could essentially influence the number and type of cross-links in collagen fibrils. That is consistent with the results of authors on changes of collagen crosslinks with diabetes [29]. Alterations in quantity of arginine, aspartic acid, threonine, serine and glutamic acid residues could cause great changes in surface charge of collagen molecules, whereas changes in quantity of methionine, isoleucine, leucine and phenylalanine residues could influence the level of collagen helix rigidity [23].

These changes in arginine, glycine and aspartic acid residues could affect the number of domains Arg-Gly-Asp which are responsible for processes of cells adhesion on collagen structures [30]. Arginine and glycine residues in collagen molecules are also parts of special locuses responsible for interactions with chaperons and for procollagen to collagen processing [31]. Additional support for such alterations in type I collagen amino acids is the fact that collagen is susceptible to formation of advanced glycation end-products (AGEs) which are accumulated as a result of hyperglycemia [32]. They are accumulated in 
bones and may exert a negative effect on bones by interfering with osteoblasts differentiation and the production of matrix proteins such as collagen [33]. Although not formally linked, it is possible that the problems with fracture repair associated with type 1 diabetes [34] are directly or indirectly related to the effects of AGEs on osteoblasts. It was recently shown that diabetes causes enhanced apoptosis of osteoblastic cells following a bacterial stimulus [35]. When apoptosis is inhibited there is a significant improvement in the capacity to form new bone demonstrating that diabetes-enhanced apoptosis is functionally important [36]. One of the mechanisms how diabetes could induce apoptosis is through stimulation by AGEs. The nature of these AGEs can be categorized as cross-linking. Intermolecular crosslinking may occur between two adjacent molecules and involve lysine to lysine or lysine to arginine residues [37]. Modification of arginine within the sites RGD and GFOGER recognized by the two specific integrins ( $\alpha 1 \beta 2$ and $\alpha 2 \beta 1)$ for collagen reduced cell interactions during turnover and platelet interactions ( $\alpha 1 \beta 2)$. These changes can ultimately affect, for example, repair of vascular damage and healing of dermal wound in diabetes. Such modifications are deleterious to the optimal properties of collagen as a supporting framework structure and as a controlling factor in cell matrix interactions. Glycosylation during diabetes is therefore responsible for malfunctioning of the diverse collagen tissues throughout the body [37].

We can suppose that above mentioned changes could be caused by deficiency of insulin which is involved into collagen synthesis regulation on different stages of this process [7]. Besides of direct influence of insulin deficiency on collagen synthesis, pathologic changes in amino acids metabolism in the whole organism with diabetes could also affect changes in collagen metabolism.

Among this, taking into account collagen genes polymorphism not only in individuals with pathologies, but also in normal ones [38], such changes could be a result of disturbances in rates of transcription of different genes from the same type I collagen superfamily as it was previously demonstrated for osteogenesis imperfecta [39].

Lowered levels of hydroxyproline in diabetic rats compared with control in our experiments could be caused by changes in vitamin $\mathrm{C}$ content. It should be noted that this may have consequences for the function of prolylhydroxylase which cofac- tor is ascorbic acid. Moreover, vitamin C deficiency may influence the collagen structure and extracellular matrix via promotion of the osteoblasts differentiation by modulating type I collagen- $\alpha 2 \beta 1$ integrin interactions [40], triggering the aggregated collagensynthesizing cells to organize their extracellular matrix [41], regulating proteoglycans biosynthesis and turnover [42] and altering mRNA levels in collagensynthesizing cells by changing the transcription rates [43]. Additionally, ascorbic acid also induced alkaline phosphatase activity, the expression of $\mathrm{mR}$ NAs for proteins that are markers of osteoblastic differentiation, the deposition of calcium [44] and increase of the rate of procollagen secretion from cells into extracellular matrix [45].

We observed, as anticipated, complete restoration of vitamin $\mathrm{B}_{3}$ content after its administration to diabetic rats as shown in Fig. 2 and 3. Chosen high dose of NAm could possibly partially improve changes of collagen structures by normalizing vitamin $C$ content. Moreover, nicotinamide preserves residual $\beta$-cells function and enhances beta-cells regeneration in partially pancreatectomized rats [14], [46]. Furthermore, it is also possible that such potential therapeutic benefits might be related to its effects as a scavenger of free radicals, to its availability as a structural component of the nicotinamide adenine dinucleotide $\left(\mathrm{NAD}^{+}\right)$, or to competitive inhibition of poly(ADP-ribose)polymerase [14, 46]. Nicotinamide and its biologically active derivative 1-methylnicotinamide also have significant neuroprotective action [47].

Other supporting data confirm the ability of administered nicotinamide to convert to $\mathrm{NAD}(\mathrm{P})^{+}$, which are used as hydrogen/electron carriers in redox reactions [48]. It is not excluded that an augmentation in $\alpha$-tocopherol levels (Fig. 3 and 4) in diabetic rats is due to markedly decreased blood serum and liver levels of vitamin $\mathrm{C}$ which is electron donor for tocopheroxyl free radicals. This observation may represent a temporal adaptation to development of oxidative stress associated with diabetes. Our study cannot provide an explanation for the observed slight decrease in $\alpha$-tocopherol levels after NAm treatment.

Thus the current study demonstrated presence of qualitative changes in rat bone type I collagen under diabetes. At this pathology could be formed bone type I collagen molecules with changed helix structure, surface charge, rigidity, number and types of cross-links and specific locuses responsible for cell adhesion, interaction with chaperons and procolla- 
gen processing to collagen. Such changes of collagen molecules could hence affect the properties and correct functioning of a number of tissues (for example processes of mineralization could be disturbed). Our supposition on collagen qualitative changes in mineralization is in good accordance with obtained data on serum alkaline phosphatase (Fig. 5). An increased release of intracellular enzymes such as ALP into the circulation induced by diabetes suggests that it is the most sensitive and dramatic indicator of hepatocytes damage [49]. So the elevated activity of this enzyme may also indicate to cellular leakage and loss of the functional integrity of the cell membranes. NAm supplementation could partially normalize these changes. Moreover, an increased expression of cytochrome P450 2E1 (Fig. 6) may be associated with elevated oxidative stress and reactive oxygen species production in diabetes, because CYP 2E1 metabolizes such endogenous compounds as fatty acids, lipid hydroperoxides and ketone bodies into aldehyde and many xenobiotics into nucleophilic reactive species [50]. These results showed that NAm treatment of diabetic rats may partially cause the protection against CYP 2E1-related oxidative stress.

Altogether, these observations suggest that collagen amino acids alterations may be both a cause and a result of bone pathology in diabetes. The current study confirms the relationship between the diabetes-associated decreases in type I collagen contents, alterations of their amino acids composition and impaired availability of vitamins. The positive effects of NAm treatment on collagen synthesis and processing, additionally with other possible contributing factors, may be attributed to preservation of vitamin $\mathrm{C}$ and $\mathrm{E}$ functions.

These findings provide evidence for using nicotinamide as a supplement to support existing therapeutic agents for prevention and treatment of type 1 diabetes as well as for the amelioration of diabetesrelated abnormalities in bone.

\section{ЕФЕКТ НІКОТИНАМІДУ НА ВМІСТ \\ АМІНОКИСЛОТ У КОЛАГЕНІ \\ КІСТОК У ЗАЛЕЖНОСТІ ВІД БІОДОСТУПНОСТІ ВІТАМІНІВ ЗА ЦУКРОВОГО ДІАБЕТУ В ЩУРІВ}

\author{
М. М. Гузик, Ю. Т. Сергійчук ${ }^{1,2}$, \\ К. О. Дякун ${ }^{1,2}$, Л. В. Яніцькка \\ T. М. Кучмеровська ${ }^{1}$
}
${ }^{1}$ Інститут біохімії ім. О. В. Палладіна НАН України, Київ;
${ }^{2}$ Київський національний університет імені Тараса Шевченка, Україна; ${ }^{3}$ Національний університет ім. О. О. Богомольця, Київ, Україна

Сполучна тканина є дуже чутливою до порушень, індукованих діабетом. За діабету зміни метаболізму різних типів колагену можуть бути асоційовані 3 розвитком остеопенії, зниженням міцності кісток тощо. Відомо, що зміни в амінокислотному складі колагену можуть значно впливати на його властивості та фізіологічні функції, однак на даний час існує недостатньо доказів залежності амінокислотного складу колагену I типу від біодоступності вітамінів, які необхідні для його синтезу. У роботі протестована здатність нікотинаміду (NAm) впливати на амінокислотний склад колагену і на доступність вітамінів за діабету. Через 4 тижні після індукції стрептозотоцинового діабету (СТ3, 60 мг/кг маси тіла) щурам-самцям лінії Wistar протягом 2 тижнів вводили NAm (200 мг/кг маси тіла). Кислотну екстракцію колагену I типу проводили за допомогою поетапного висолювання. Амінокислотний склад аналізували методом катіонообмінної хроматографії. У щурів за діабету виявлені зміни амінокислотного складу колагену I типу, головним чином значне зниження вмісту залишків о-Pro, Gly, Ala, o-Lys та Pro та збільшення вмісту залишків Lys, His, Arg, Glu, 
Thr, Leu, Phe $(P<0,05)$. Введення NAm частково нормалізувало амінокислотний склад колагену. Вміст вітамінів $\mathrm{C}$ та $\mathrm{B}_{3}$ у крові та печінці щурів 3 діабетом був значно знижений, тоді як рівень $\alpha$-токоферолу був підвищений у порівнянні 3 контролем $(P<0,05)$. Введення NAm діабетичним щурам нормалізувало вміст вітамінів $\mathrm{C}$ та $\mathrm{B}_{3}$ у крові та печінці. Одержані дані свідчать про функціональний зв'язок між асоційованими 3 діабетом змінами в амінокислотному складі колагену та забезпеченістю вітамінами, які необхідні для його синтезу. Таким чином, нікотинамід може знайти застосування при лікуванні порушень метаболізму в кістках, індукованих цукровим діабетом.

К лючов і слов а: нікотинамід, стрептозотоциновий діабет у щурів, амінокислотний склад колагену кісток, вітамін $\mathrm{C}$, вітамін $\mathrm{B}_{3}$, $\alpha$-токоферол.

ЭФФЕКТ НИКОТИНАМИДА НА
СОДЕРЖАНИЕ АМИНОКИСЛОТ
В КОЛЛАГЕНЕ КОСТЕЙ
В ЗАВИСИМОСТИ ОТ
БИОДОСТУПНОСТИ ВИТАМИНОВ
ПРИ САХАРНОМ ДИАБЕТЕ У КРЫС

\section{М. М. Гузик', Ю. Т. Сергейчук $\kappa^{1,2}$, К. О. Дякун ${ }^{1,2}$, Л. В. Яниикая ${ }^{3}$, T. М. Кучмеровская ${ }^{1}$}
${ }^{1}$ Институт биохимии им. А. В. Палладина НАН Украины, Киев;
${ }^{2}$ Киевский национальный университет имени Тараса Шевченко, Украина;
${ }^{3}$ Национальный медицинский университет им. А. А. Богомольца, Киев, Украина

Соединительная ткань очень чувствительна к нарушениям, индуцированным диабетом. При диабете изменения метаболизма разных типов коллагена могут быть ассоциированы с развитием остеопении, снижением прочности костей и т.п. Известно, что изменения в аминокислотном составе коллагена могут значительно влиять на его свойства и физиологические функции, однако в настоящее время имеется недостаточно доказательств зависимости аминокислотного состава коллагена I типа от биодоступности витаминов, которые необходимы для его синтеза. В работе протестирована способность никотинамида (NAm) влиять на аминокислотный состав кол- лагена и на доступность витаминов при диабете. После 4 недель индукции стрептозотоцинового диабета (СТ3, 60 мг / кг массы тела) самцам крыс линии Wistar на протяжении двух недель вводили NAm (200 мг / кг массы тела). Кислотную экстракцию коллагена I типа проводили с помощью поэтапного высаливания. Аминокислотный состав анализировали методом катионообменной хроматографии. У крыс с диабетом обнаружено изменение аминокислотного состава коллагена I типа, главным образом, значительное снижение количества остатков o-Pro, Gly, Ala, o-Lys и Pro и увеличение остатков Lys, His, Arg, Glu, Thr, Leu, Phe $(P<0,05)$. Введение NAm частично нормализовало аминокислотный состав коллагена. Содержание витаминов $\mathrm{C}$ и $\mathrm{B}_{3}$ в крови и печени крыс с диабетом было значительно снижено, в то время как уровень $\alpha$-токоферола был повышен по сравнению с контролем $(P<0,05)$. Введение NAm диабетическим крысам нормализовало содержание витаминов $\mathrm{C}$ и $\mathrm{B}_{3}$ в крови и печени. Полученные данные свидетельствуют о функциональной связи между ассоциированными с диабетом изменениями в аминокислотном составе коллагена и обеспеченности витаминами, которые необходимы для его синтеза. Таким образом, никотинамид может быть использован для лечения нарушений метаболизма в костях индуцированных сахарным диабетом.

К лючевы е с лов а: никотинамид, стрептозотоциновый диабет у крыс, аминокислотный состав коллагена костей, витамин С, витамин $\mathrm{B}_{3}, \alpha$-токоферол.

\section{References}

1. Todd J. A. Etiology of type 1 diabetes. // Immunity. - 2010. - 32, N 4. - P. 457-467.

2. Eisenbarth G. S. Update in type 1 diabetes // J. Clin. Endocr. Metab. - 2007. - 92, N 7. P. 2403-2407.

3. Sego S. Pathophysiology of diabetic nephropathy // J. Nephrol. Nurs. - 2007. - 34, N 6. - P. 631633.

4. Skyler J. Update on worldwide efforts to prevent type 1 diabetes // Ann. N. Y. Acad. Sci. - 2008. 1150. - P. 190-196.

5. Nieto N., Friedman S. L., Cederbaum A. I. Cytochrome P450 2E1-derived reactive oxygen species mediate paracrine stimulation of collagen I protein synthesis by hepatic stellate 
cells // J. Biol. Chem. - 2002. - 277, N 12. P. 9853-9864.

6. Lehti T. M., Silvennoinen M., Kivela R., Kainulainen $H$., Komulainen $J$. Effects of streptozotocin-induced diabetes and physical training on gene expression of titin-based stretchsensing complexes in mouse striated muscle // Am. J.Physiol. Endocr. Metab. - 2007. - 292, N 2. - P. 533-542.

7. Thrailkill K. M., Lumpkin C. K., Bunn R. C., Kemp S. F., Fowlkes J. L. Is insulin an anabolic agent in bone? Dissecting the diabetic bone for clues // Am. J. Physiol. Endocrinol. Metab. 2005. - 289, N 5. - P. 735-745.

8. Rossert J., Terraz C., Dupont S. Regulation of type I collagen genes expression // Nephrol. Dial. Transplant. - 2000. - 15, Suppl. 6. - P. 66-68.

9. Hamilton E. J., Rakic V., Davis W. A., Chubb S. A. P., Kamber N., Prince R. L., Davis T. M. E. Prevalence and predictors of osteopenia and osteoporosis in adults with Type 1 diabetes // Diab. Med. - 2009. - 26, N 1. - P. 45-52.

10. Gass R. The early preclinical diagnosis of osteoporosis measuring the pure trabecular bone density // Eur. J. Med. Res. - 2001. - 6, N 5. P. $228-230$.

11. Naidu K. A. Vitamin $\mathrm{C}$ in human health and disease is still a mystery? An overview // Nutr. J. - 2003. - 2. - P. 7.

12. Arjmandi B., Juma S., Beharka A., Bapna M., Akhter M., Meydani S. Vitamin E improves bone quality in the aged but not in young adult male mice // J. Nutr. Biochem. - 2002. - 13, N 9. P. 543-549.

13. Smith B. J., Lucas E. A., Turner R. T., Evans G. L., Lerner M. R., Brackett D. J., Stoecker B. J., Arjmandi B. H. Vitamin E provides protection for bone in mature hindlimb unloaded male rats // Calcif. Tissue Int. - 2005. - 76, N 4. - P. 272-279.

14. Kolb H., Burkart V. Nicotinamide in type 1 diabetes. Mechanism of action revisited // Diabetes Care. - 1999. - 22, Suppl. 2. - P. 16-20.

15. Vaca P., Berná G., Araujo R., Carneiro E. M., Bedoya F. J., Soria B., Martín F. Nicotinamide induces differentiation of embryonic stem cells into insulin-secreting cells // Exp. Cell Res. 2008. - 314, N 5. - P. 969-974.

16. Edwin E. E., Diplock A. T., Bunyan J., Green J. Studies on Vitamin E // Biochem. J. - 1960. - 75, N 3. - P. 450-456.
17. Bellion E. Rapid spectrophotometric assay for nicotinic acid // Anal. Biochem. - 1968. - 25. P. $578-582$.

18. Omaye S. T., Turnbull J. D., Sauberlich H. E. Selected methods for the determination of ascorbic acid in animal cells, tissues, and fluids // Methods Enzymol. - 1979. - 62. - P. 3-11.

19. Tietz N. W., Burtis C. A., Duncan P., Ervin K., Petitclerc C. J., Rinker A. D., Shuey D., Zygowicz E. R. A reference method for measurement of alkaline phosphatase activity in human serum // Clin.Chem. - 1983. - 29, N 5. P. 751-761.

20. Trelstad R. L., Catanese V. M., Rubin D. F. Collagen fractionation: separation of native types I, II and III by differential precipitation // Anal. Biochem. - 1976. - 71, N 1. - P. 114-118.

21. Miller E. J., Rhodes R. K. Preparation and characterization of the different types of collagen // Method. Enzymol. - 1982. - 82. - P. 33-64.

22. Rajan N., Habermehl J., Coté M. F., Doillon C. J., Mantovani D. Preparation of ready-to-use, storable and reconstituted type I collagen from rat tail tendon for tissue engineering applications // Nat. Protoc. - 2006. - 1, N 6. - P. 2753-2758.

23. Saito $M$. Poor bone quality in diabetes: detrimental collagen cross-link pattern reduces bone strength without change in bone mineral density // Clinical Calcium. - 2006. - 16, N 8. P. 1287-1295.

24. Stinson R. A., Hamilton B. A. Human liver plasma membranes contain an enzyme activity that removes membrane anchor from alkaline phosphatase and converts it to a plasma-like form // Clin. Biochem. - 1994. - 27, N 1. - P. 49-55.

25. Seibel M. J. Biochemical markers of bone turnover: part 1: biochemistry and variability // Clin. Biochem. Rev. - 2005. - 26, N 4. - P. 97-122.

26. Golub E. E., Boesze-Battaglia K. The role of alkaline phosphatase in mineralization.// Curr. Opin. Orthop. - 2007. - 18, N 5. - P. 444-448.

27. Kim B. M., Eichler J., Reiser K. M., Rubenchik A. M., Da Silva L. B. Collagen structure and nonlinear susceptibility: effects of heat, glycation, and enzymatic cleavage on second harmonic signal intensity // Lasers Surg. Med. 2000. - 27, N 4. - P. 329-335.

28. Yavuz D., Tuğtepe H., Cetinel S., Uyar S., Kaya H., Haklar G., Civelek S., Deyneli O., San T., Burçak G., Akalin S. Collagen ultrastructure and TGF-betal expression 
preserved with aminoguanidine during wound healing in diabetic rats // Endocr. Res. - 2005. 31, N 3. - P. 229-243.

29. Saito M., Marumo K. Collagen cross-links as a determinant of bone quality: a possible explanation for bone fragility in aging, osteoporosis, and diabetes mellitus // Osteoporis Int. - 2010. - 21, N 2. - P. 195-214.

30. Loeser R. F., Wallin R. Cell adhesion to matrix Gla protein and its inhibition by an Arg-GlyAsp-containing peptide // J. Biol.Chem. 1992. - 267, N 14. - P. 9459-9462.

31. Koide T., Takahara Y., Asada S., Nagata K. XaaArg-Gly triplets in the collagen triple helix are dominant binding sites for the molecular chaperone HSP47 // J. Biol. Chem. - 2002. - 277, N 8. - P. 6178-6182.

32. Reddy G. K. Cross-linking in collagen by nonenzymatic glycation increases the matrix stiffness in rabbit achilles tendon // Exp. Diabetes Res. - 2004. - 5, N 2. - P. 143-153.

33. Santana R. B., Xu L., Chase H. B., Amar S., Graves D. T., Trackman P. C. A role for advanced glycation end products in diminished bone healing in type 1 diabetes // Diabetes. - 2003. 52, N 6. - P. 1502-1510.

34. Schurman L., McCarthy A. D., Sedlinsky C., Gangoiti M. V., Arnol V., Bruzzone L., Cortizo A. M. Metformin reverts deleterious effects of advanced glycation endproducts (AGEs) on osteoblastic cells // Exp. Clin. Endocrinol. Diabetes. - 2008. - 116, N 6. P. 333-340.

35. He H., Liu R., Desta T., Leone C., Gerstenfeld L.C., Graves D. T. Diabetes causes decreased osteoclastogenesis, reduced bone formation, and enhanced apoptosis of osteoblastic cells in bacteria stimulated bone loss // Endocrinology. 2004. - 145, N 1. - P. 447-452.

36. Al-Mashat H. A., Kandru S., Liu R., Behl Y., Desta T., Graves D. T. Diabetes enhances mRNA levels of proapoptotic genes and caspase activity, which contribute to impaired healing // Diabetes. - 2006. - 55, N 2. - P. 487-495.

37. Avery N. C., Bailey A. J. The effects of the Maillard reaction on the physical properties and cell interactions of collagen // Pathol. Biol. 2006. - 54, N 7. - P. 387-395.

38. Blades H. Z., Arundel P., Carlino W. A., Dalton A., Crook J. S., Freeman J. V., Bishop N. J. Collagen gene polymorphisms influence fracture risk and bone mass acquisition during childhood and adolescent growth // Bone. - 2010. - 47, N 5. P. 989-994.

39. Wirtz M. K., Rao V. H., Glanville R. W., Labhard M. E., Pretorius P. J., de Vries W. N., de Wet W. J., Hollister D. W. A cysteine for glycine substitution at position 175 in an alpha 1 (I) chain of type I collagen produces a clinically heterogeneous form of osteogenesis imperfecta // Connect. Tissue Res. - 1993. - 29, N 1. - P. 1-11. 40. Ishikawa S., Iwasaki K., Komaki M., Ishikawa I. Role of ascorbic acid in periodontal ligament cell differentiation // J. Periodontol. - 2004 . - 75, N 5. - P. 709-716.

41. Dozin B., Quarto R., Campanile G., Cancedda R. In vitro differentiation of mouse embryo chondrocytes: requirement for ascorbic acid // Eur. J. Cell Biol. - 1992. - 58, N 2. - P. 390-394.

42. Blumberg P., Brenner R., Budny S., Kresse H. Increased turnover of small proteoglycans synthesized by human osteoblasts during cultivation with ascorbate and betaglycerophosphate // Calcified Tissue Int. 1997. - 60, N 6. - P. 554-560.

43. Sullivan T. A., Uschmann B., Hough R., Leboy P. S. Ascorbate modulation of chondrocyte gene expression is independent of its role in collagen secretion // J. Biol. Chem. - 1994. - 269, N 36. P. 22500-22506.

44. Otsuka E., Yamaguchi A., Hirose S., Hagiwara H. Characterization of osteoblastic differentiation of stromal cell line ST2 that is induced by ascorbic acid // Am. J. Physiol. - 1999. - 277. P. 132-138.

45. Franceschi R. T. Effects of ascorbic acid on collagen matrix formation and osteoblast differentiation in murine MC3T3-E1 cells // J. Bone Miner. Res. - 1994. - 9, N 6. - P. 843-854.

46. Kuchmerovska T., Shymanskyy I., Donchenko G., Kuchmerovskyy M., Pakirbaieva L., Klimenko A. Poly(ADP-ribosyl)ation enhancement in brain cell nuclei is associated with diabetic neuropathy // J. Diabetes Complicat. - 2004. - 18, N 4. P. 198-204.

47. Kuchmerovska T., Shymanskyy I., Chlopicki S., Klimenko A. 1-methylnicotinamide (MNA) in prevention of diabetes-associated brain disorders // Neurochem. Int. - 2010. - 56, N 2. P. 221-228. 
48. Bolander F. F. Vitamins: not just for enzymes // Curr. Opin. Investig. Drugs. - 2006. - 7, N 10. P. 912-915.

49. Sallie R., Tredger J. M., Williams R. Drugs and the liver. Part 1: Testing liver function // Biopharm. Drug Dispos. - 1991. - 12, N 4. - P. 251-259.
50. Marí M., Cederbaum A. I. Induction of catalase, alpha, and microsomal glutathione S-transferase in CYP2E1 overexpressing HepG2 cells and protection against short-term oxidative stress // Hepatology. - 2001. - 33, N 3. - P. 652-661.

Received 15.11.2013 